\title{
BIODEGRADATION OF POLYCYCLIC AROMATIC HYDROCARBONS BY SOIL FUNGI
}

\author{
Andrea R. Clemente; Tania A. Anazawa; Lucia R. Durrant* \\ Departamento de Ciência de Alimentos, Faculdade de Engenharia de Alimentos, Universidade Estadual de Campinas, \\ Campinas, SP, Brasil
}

Submitted: June 26, 2000; Returned to authors for corrections: September 05, 2000; Approved: November 21, 2001

\begin{abstract}
Thirteen deuteromycete ligninolytic fungal strains were grown in media containing polycyclic aromatic hydrocarbons (PAHs), for 6 and 10 days. The PAHs were added directly with the inocula or on the third day of cultivation. A selection of the best strains was carried out based on the levels of degradation of the PAHs and also on the ligninolytic activities produced by the fungi. The selected strains were cultivated for 3, 6, 9, 12 and 15 days in the PAHs-containing media. Degradation of PAHs, as measured by reversed-phase HPLC on a $\mathrm{C}_{18}$ column, varied with each strain as did the ligninolytic enzymes present in the culture supernatants. Highest degradation of naphthalene $(69 \%)$ was produced by the strain 984 , having Mn-peroxidase activity, followed by strain $870(17 \%)$ showing lignin peroxidase and laccase activities. The greatest degradation of phenanthrene (12\%) was observed with strain 870 containing Mn-peroxidase and laccase activities. When anthracene was used, the strain 710 produced a good level of degradation $(65 \%)$.
\end{abstract}

Key words: biodegradation, ligninolytic enzymes, polycyclic aromatic hydrocarbons, fungi.

\section{INTRODUCTION}

Polycyclic aromatic hydrocarbons (PAHs) are fused ring aromatic compounds, ubiquitous pollutants in the atmosphere and relatively resistant to biodegradation. PAHs can therefore accumulate to substantial levels in the environment and have been detected in a wide range of soils and sediments, including some ancient sediments $(10,15)$. There are more than 70 compounds classed as PAHs having from 2 to 7 rings. Since the larger compounds are carcinogenic, they can pose a significant health hazard. PAHs are produced in large quantities by cooking operations and gasification processes using coal and from other sources of incomplete combustion such as automobile exhausts, power generation plants, refuse burning and industrial emissions $(6,9)$. Significant quantities are present in both industrial and domestic effluents causing problems in wastewater treatments. Another source is hydrocarbon spills $(2,16)$. PAHs can also have a natural origin in coal deposits, from natural aromatics such as terpenes, sterols and quinones from plants, which volatilize and can become condensed to PAHs. Plant lignins may also become progressively decomposed to humic substances, which can become larger during maturation of the peat or coal deposits and can eventually produce PAHs $(7,13)$.

The white rot fungi, such as Phanerochaete chrysosporium, are wood decomposing basidiomycetes that can degrade not only lignin but also a broad spectrum of recalcitrant environmental organopollutants, including PAHs, which are not readily degraded by other microorganisms $(4,14)$. This degradative activity is due to the lignin-degrading systems of these fungi, which is composed by enzymes such as lignin peroxidase (EC 1.11.1.7), manganese peroxidase (EC 1.11.1.7) and laccase (EC 1.10.3.2) (1,12,18).

The objective of this study was to determine whether nonbasidiomycete ligninolytic soil fungi can degrade PAHs and to evaluate the production of the ligninolityc enzymes during growth of the fungi in these hydrocarbons.

\footnotetext{
* Corresponding author. Mailing address: Departamento de Ciência de Alimentos, FEA/UNICAMP, CP 6121. 13081-970, Campinas, SP, Brasil. E-mail: durrant@fea.unicamp.br
} 


\section{MATERIALS AND METHODS}

\section{Fungal strains and inocula preparation}

The 13 fungal strains isolated from soil samples collected at the Jureia/Itatins ecological reserve (São Paulo - Brazil) and classified as deuteromycetes, were a gift from the Tropical Culture Collection - Fundação Tropical André Tosello, Campinas-SP. This region presents high concentrations of tannic and humic acids, originating from lignocellulose biodegradation. The strains were maintained on PDA (potato dextrose agar-DIFCO) slants. Petri dishes containing PDA were inoculated with a mycelium portion of each strain and incubated at $30^{\circ} \mathrm{C}$ for $8-10$ days, after which the agar was cut and either $1 \mathrm{~cm}^{2}$ or $3 \times 1 \mathrm{~cm}^{2}$ mycelial pieces were removed with a thin spatula and used as the inocula for the experiments described below.

\section{Culture conditions}

The fungal strains were inoculated $\left(1 \mathrm{~cm}^{2}\right)$ in liquid medium (30 mL/250 mL Erlenmeyer flasks) containing per liter: 0.5 $\mathrm{g}\left(\mathrm{NH}_{4}\right)_{2} \mathrm{HPO}_{4}, 0.8 \mathrm{~g} \mathrm{KH}_{2} \mathrm{PO}_{4}, 0.3 \mathrm{~g} \mathrm{~K}_{2} \mathrm{HPO}_{4}, 0.3 \mathrm{~g}$ $\mathrm{MgSO}_{4} .7 \mathrm{H}_{2} \mathrm{O}, 0.055 \mathrm{~g} \mathrm{CaCl}_{2} .2 \mathrm{H}_{2} \mathrm{O}, 4.0 \mathrm{mg} \mathrm{ZnSO}_{4} .6 \mathrm{H}_{2} \mathrm{O}$, $0.2 \mathrm{~g}$ yeast extract and $1.0 \mathrm{~mL}$ thiamine $(2.0 \mathrm{mg} / \mathrm{mL})$. The carbon sources naphthalene, phenanthrene or anthracene were added either together with the inoculum and incubated for 6 days or on the $3^{\text {rd }}$ day of cultivation and incubated for 10 days. The strains causing the greatest degradation of PAHs were selected, inoculated $3 \times 1 \mathrm{~cm}^{2}$ in the medium described above, and incubated for 3, 6, 9, 12 and 15 days. $300 \mu \mathrm{L}$ of a $5.0 \%(\mathrm{w} / \mathrm{v})$ naphthalene or phenanthrene solution in acetone or $3.0 \mathrm{~mL}$ of a $0.5 \%$ anthracene in acetone was used per flask, and added together with the inoculum. The final $\mathrm{pH}$ of the culture media was 5.0. Following inoculation all cultures were incubated under stationary conditions at $30^{\circ} \mathrm{C}$. To correct for the loss of PAHs, controls were prepared with uninoculated flasks. All experiments were run in duplicates.

\section{Enzyme assays}

Lignin peroxidase ( $\mathrm{LiP})$, manganese peroxidase $(\mathrm{MnP})$, and laccase (Lac.) activities were assayed spectrophotometrically in the extracellular fluid of the culture supernatants. LiP was determined by measuring veratryl alcohol oxidation as described previously (22). MnP determinations were based on the oxidation of phenol red, according to Kuwahara et al. (19). Laccase was determined via the $\mathrm{H}_{2} \mathrm{O}_{2}$-independent oxidation of syringaldazine (ethanol solution) to its quinone form (21). The supernatants were obtained following centrifugation of the content of whole flasks at 17,000 rpm for $30 \mathrm{~min}$ at $5^{\circ} \mathrm{C}$. All the enzyme activities are expressed in units per liter, where one units equal to $1 \mu \mathrm{mol}$ of substrate oxidized per minute.

\section{High performance liquid chromatography (HPLC)}

All HPLC analyses were performed with a Zorbax ODS (0.46 $\mathrm{x} 15 \mathrm{~cm}$ ) $\mathrm{C}_{18}$ reverse-phase column (SUPELCO Chromatography Products). Separation was achieved by isocratic elution in acetonitrile: water (70:30), with a flow rate of $0.8 \mathrm{~mL} / \mathrm{min}$ and $\mathrm{UV}$ absorbance detector set at $279 \mathrm{~nm}$ for naphthalene and phenantrene. Anthracene was detected at $254 \mathrm{~nm}$ at a flow rate of $1.0 \mathrm{~mL} / \mathrm{min}$.

\section{RESULTS AND DISCUSSION}

All the fungal strains used in this work exhibited some ligninolytic activity and degradation after growth in the PAHs, which varied with the time of growth and also with the carbon source.

Table 1 shows the greatest values of the activities of the enzymes produced after growth of all 13 strains in naphthalene.

Low levels of LiP activity were produced by strains 480,870 and 897. Higher levels of $\mathrm{MnP}$ when compared to LiP and laccase were produced by most of the 13 strains.

Strains 870 and 984 showed the highest degradation of naphthalene (Table 4) among the 13 strains, following 6 days of growth. Strain 870 exhibited maximal $\mathrm{LiP}$ and laccase activities on the $10^{\text {th }}$ and $6^{\text {th }}$ day, whereas $\mathrm{MnP}$ was only detected on the $10^{\text {th }}$ (Table 1). Strain 984 did not show any LiP activity; laccase and $\mathrm{MnP}$ activities were higher on the $6^{\text {th }}$ day than on the $10^{\text {th }}$ (Table 1). These results indicate that these two strains express their ligninolytic system differently when growing in naphthalene.

Table 1. Maximal ligninolytic activities produced following the growth of the fungi in naphthalene.

\begin{tabular}{cccc}
\hline Strain & $\begin{array}{c}\text { Lignin } \\
\text { peroxidase }\end{array}$ & $\begin{array}{c}\text { Manganese } \\
\text { peroxidase }\end{array}$ & Laccase (6) \\
\hline 480 & $0.053(10)^{\mathrm{b}}$ & $0.45(10)$ & 0.26 \\
490 & $\mathrm{ND}^{\mathrm{a}}$ & $2.61(6)$ & 1.3 \\
582 & $\mathrm{ND}$ & $67.41(6)$ & 0.48 \\
710 & $\mathrm{ND}$ & $23.22(6)$ & 0.89 \\
756 & $\mathrm{ND}$ & $10.0(6)$ & 0.91 \\
801 & $\mathrm{ND}$ & $11.7(6)$ & 0.94 \\
837 & $\mathrm{ND}$ & $\mathrm{ND}$ & 0.96 \\
870 & $0.18(10)$ & $8.82(10)$ & 1.00 \\
897 & $0.12(6)$ & $2.88(10)$ & 0.65 \\
898 & $\mathrm{ND}$ & $2.88(10)$ & 1.20 \\
984 & $\mathrm{ND}$ & $2.61(6)$ & 0.73 \\
1040 & $\mathrm{ND}$ & $27.72(6)$ & 0.64 \\
1051 & $\mathrm{ND}$ & $\mathrm{ND}$ & 0.91 \\
\hline
\end{tabular}

a) ND: Not Detected. b) The numbers in brackets are the growth times in days for the highest activities produced by the strains. The SD of each of the values is $<5 \%$. 
Table 2 shows the highest values of the enzymes activities produced following growth of the 13 strains in phenanthrene. All the strains were able to grow in this carbon source.

Strains 837, 870 and 984 showed high degradation of this carbon source following 10 days of growth (Table 4). Maximal values of $\mathrm{MnP}$ were produced on the $10^{\text {th }}$ day by the strain 837 , and on the $6^{\text {th }}$ day by the strains 870 and 984 . Laccase was produced by these 3 strains both on the $6^{\text {th }}$ and $10^{\text {th }}$ days of growth, whereas low levels of LiP activities were produced by strains 837 and 870 on the $6^{\text {th }}$ and $10^{\text {th }}$ days respectively (Table 2).

Table 3 shows the maximal values of the activities of the enzymes produced after growth of all 13 strains in anthracene.

Strains 710, 870 and 984 showed the highest degradation of anthracene (Table 4). As shown in Table 3, the enzymes of their ligninolytic system were also expressed differently when these 3 strains used anthracene as the carbon source. LiP and laccase were produced by the strains 710 and 984 on the $10^{\text {th }}$ and $6^{\text {th }}$ day, respectively. $\mathrm{MnP}$ was produced by strains 710 and 984 on the $6^{\text {th }}$ day, but strain 870 expressed this activity only on the $10^{\text {th }}$ day.

The strains causing the greatest degradation of the PAHs, 870 and 984 in naphthalene, 837, 870 and 984 in phenanthrene, and 710, 870 and 984 in anthracene, were selected and used for more detailed analyses of growth and degradation of PAHs, as described under culture conditions.

Fig. 1 shows the activities of the enzymes produced after growth of the fungal strains (870 and 984) in naphthalene.

Table 2. Maximal ligninolytic activities produced following growth of the fungi in phenanthrene.

\begin{tabular}{cccl}
\hline Strain & $\begin{array}{c}\text { Lignin } \\
\text { peroxidase }\end{array}$ & $\begin{array}{c}\text { Manganese } \\
\text { peroxidase }\end{array}$ & Laccase \\
\hline 480 & $0.05(10)^{\mathrm{B}}$ & $8.28(10)$ & $0.4(10)$ \\
490 & $0.6(10)$ & $6.57(10)$ & $0.29(10)$ \\
582 & $0.19(10)$ & $0.81(10)$ & $\mathrm{ND}$ \\
710 & $\mathrm{ND}^{\mathrm{a}}$ & $5.49(6)$ & $0.3(6-10)$ \\
756 & $\mathrm{ND}$ & $7.2(6)$ & $0.31(10)$ \\
801 & $\mathrm{ND}$ & $\mathrm{ND}$ & $0.41(10)$ \\
837 & $0.071(6)$ & $3.87(10)$ & $0.28(6)$ \\
870 & $0.02(10)$ & $4.23(6)$ & $0.51(6)$ \\
897 & $\mathrm{ND}$ & $1.44(6)$ & $0.125(10)$ \\
898 & $0.7(6)$ & $5.31(6)$ & $0.43(10)$ \\
984 & $\mathrm{ND}$ & $7.38(6)$ & $0.35(10)$ \\
1040 & $0.02(10)$ & $1.35(6)$ & $0.22(10)$ \\
1051 & $\mathrm{ND}$ & $3.96(6)$ & $0.45(10)$ \\
\hline
\end{tabular}

a) ND: Not Detected. b) The numbers in brackets are the growth times in days for the highest activities produced by the strains. The SD of each of the values is $<5 \%$.
Table 3. Maximal ligninolytic activities produced following growth of the strains in anthracene.

\begin{tabular}{rccl}
\hline Strain & $\begin{array}{c}\text { Lignin } \\
\text { peroxidase }\end{array}$ & $\begin{array}{c}\text { Manganese } \\
\text { peroxidase }\end{array}$ & Laccase \\
\hline 480 & $0.125(10)^{\mathrm{b}}$ & $4.14(6)$ & $0.13(10)$ \\
490 & $\mathrm{~N}^{\mathrm{a}}$ & $4.59(6)$ & $0.35(6 / 10)$ \\
582 & $0.143(10)$ & $10.26(6)$ & $0.15(6)$ \\
710 & $0.125(10)$ & $8.73(6)$ & $0.22(10)$ \\
756 & $\mathrm{~N} . \mathrm{D}$ & $6.75(6)$ & $0.44(6)$ \\
801 & $1.34(10)$ & $7.65(10)$ & $0.36(6)$ \\
837 & $\mathrm{~N} . \mathrm{D}$ & $8.46(10)$ & $0.65(10)$ \\
870 & $\mathrm{~N} . \mathrm{D}$ & $2.97(10)$ & $0.53(10)$ \\
897 & $0.23(10)$ & $6.39(10)$ & $0.24(6)$ \\
898 & $0.3(10)$ & $10.17(6)$ & $0.5(6)$ \\
984 & $0.02(6)$ & $5.94(6)$ & $0.4(6)$ \\
1040 & $0.34(6)$ & $9.87(6)$ & $0.03(6)$ \\
1051 & N.D & $8.82(6)$ & $0.74(10)$ \\
\hline
\end{tabular}

a) ND: Not Detected. b) The numbers in brackets are the growth times in days for the highest activities produced by the strains. The SD of each of the values $\mathrm{s}<5 \%$.

Table 4. Degradation produced by the strains after growth in PAHs.

\begin{tabular}{rcccccc}
\hline \multirow{2}{*}{ Strain } & \multicolumn{2}{c}{ Naphthalene } & \multicolumn{2}{c}{ Phenanthrene } & \multicolumn{2}{c}{ Anthracene } \\
\cline { 2 - 7 } & 6 days & 10 days & 6 days & 10 days & 6 days & 10 days \\
\hline 480 & 32.27 & ND & ND & ND & 44.66 & 27.45 \\
490 & ND $^{\text {a }}$ & ND & ND & 78.66 & 15.10 & 56.05 \\
582 & ND & 5.40 & ND & 43.22 & 55.60 & 49.93 \\
710 & 19.32 & 39.07 & 39.11 & 66.24 & 59.00 & 57.16 \\
756 & 18.57 & 22.05 & ND & 69.57 & 50.15 & 51.42 \\
801 & 0.52 & 29.07 & ND & 7.51 & 51.98 & 36.03 \\
837 & ND & ND & ND & 86.70 & 51.68 & 50.40 \\
870 & 62.39 & ND & ND & 94.76 & 60.21 & 63.22 \\
897 & 43.21 & 12.21 & ND & 79.56 & ND & 25.46 \\
898 & ND & ND & 1.27 & 90.88 & 4.01 & 26.74 \\
984 & 80.35 & 24.05 & ND & 85.89 & 49.19 & 58.85 \\
1040 & 27.77 & ND & ND & 48.98 & 50.58 & 41.50 \\
1051 & 37.98 & 24.71 & ND & 65.23 & 48.12 & 50.62 \\
\hline
\end{tabular}

a) ND: Not Detected. The SD of each of the values is $<10 \%$.

When naphthalene was used as the carbon source for growth of the strains 870 and 984, the enzyme MnP exhibited the highest activity. For each day on which activity was measured, strain 870 (Fig. 1 A) produced $\mathrm{MnP}$ and very low levels of LiP, and laccase activities. Strain 984 (Fig. 1 B) exhibited low levels of LiP and laccase activities only on the $3^{\text {rd }}$ and $6^{\text {th }}$ days and $\mathrm{MnP}$ was detected from the $6^{\text {th }}$ day on. These two strains were able to degrade naphthalene after the 

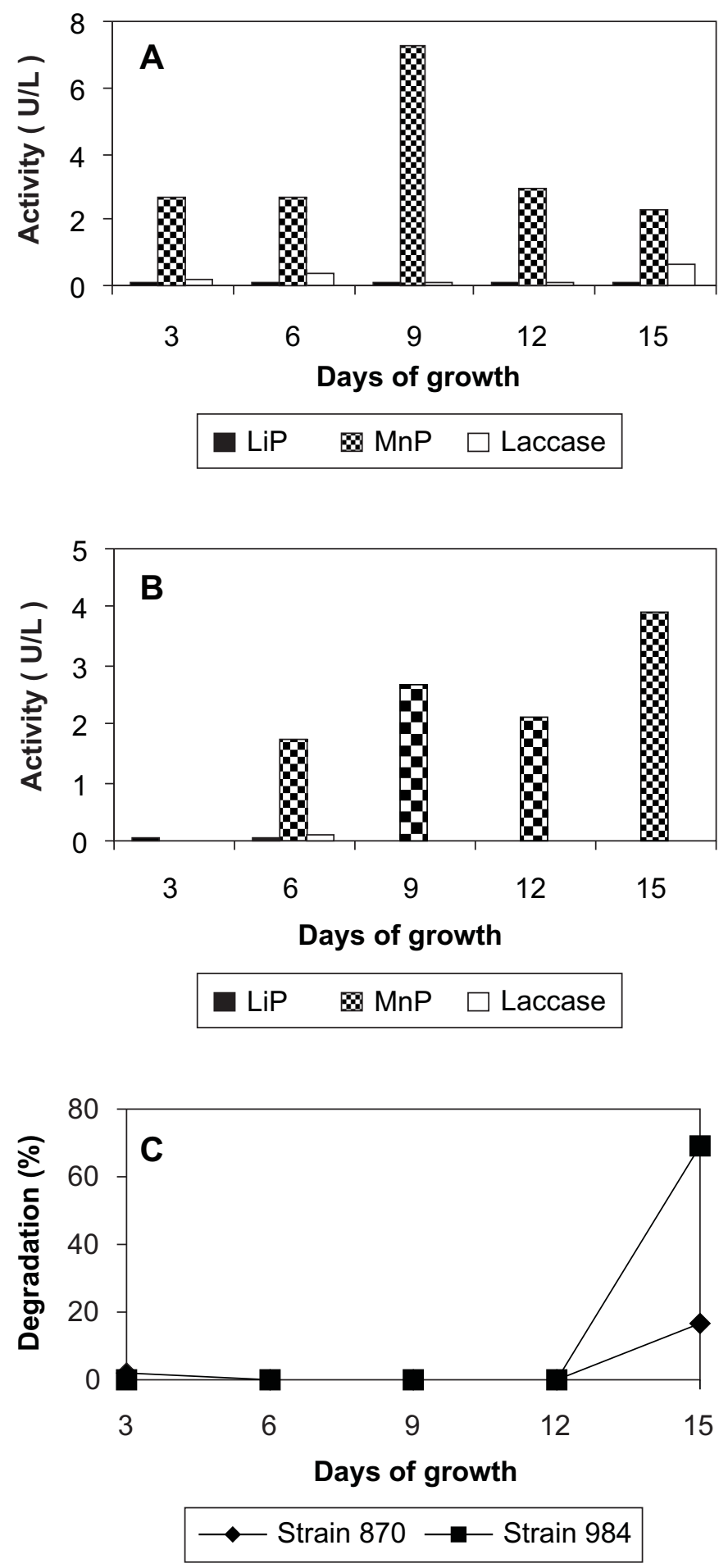

Figure 1. Activity of ligninolytic enzymes and degradation produced following growth of the strains in naphthalene. A) enzyme activity of strain 870; B) enzyme activity of strain 984; C) degradation of both strains. $12^{\text {th }}$ day of growth and a maximum degradation of $17 \%$ and 69 $\%$ were produced by the strains 870 and 984 , respectively (Fig. 1C).

Fig. 2 shows the activities of the enzymes produced after growth of the fungal strains $(837,870$ and 984) in phenanthrene.

When phenanthrene was used as the carbon source for growth of the strains 837,870 and 984 , the highest enzyme activities were also produced by MnP, which was detected in all the days assayed. Lower levels of laccase was produced by these three strains in most of the days in which it was assayed and LiP activities present were negligible when compared to the other two enzymes (Fig. 2). Maximum degradation of phenanthrene by these three strains was obtained on the $3^{\text {rd }}$ day of growth. However, when $1 \mathrm{~cm}^{2}$ mycelial piece was used as inoculum, a much higher level of degradation was produced not only by these three strains, but also for most of the others studied in the first part of this work (Table 4), strongly indicating the effect of the size of the inoculum in the degradation of phenanthrene by these fungi. The participation of surfactant-like compounds produced by these strains and other basidiomycete fungi when growing on aromatic hydrocarbons, which solubilize the PAH, leading to an increase in the concentration in the medium, which could in turn cause inhibition of the degradation process can not be ruled out $(5,8,17,23,24)$. It is possible that a longer growth period is necessary for greater degradation.

Fig. 3 shows the activities of the enzymes and the degradation produced following growth of the fungal strains $(710,870$ and 984) in anthracene.

When anthracene was used as the carbon source for growth of strains 710, 870 and 984 the enzyme MnP also exhibited the highest activities.

Strain 710 (Fig. 3 A) produced LiP activity only on the $3^{\text {rd }}$ day, $\mathrm{MnP}$ and laccase activities were exhibited on all the days on which measurements were made, except on the $9^{\text {th }}$ and $15^{\text {th }}$ days of growth, respectively. Strain 870 (Fig. 3 B) exhibited LiP activity on the $3^{\text {rd }}$ and $15^{\text {th }}$ days, MnP was produced on every day in which it was analysed except on the $12^{\text {th }}$, and laccase activity was produced on the $3^{\text {rd }}, 6^{\text {th }}, 9^{\text {th }}$ and $12^{\text {th }}$ days of growth. Strain 984 (Fig. 3 C) produced LiP activity only on $15^{\text {th }}$ day, MnP activity on the $6^{\text {th }}, 9^{\text {th }}$ and $12^{\text {th }}$ days and laccase activity only on the $12^{\text {th }}$ day of growth. These strains were able to degrade anthracene (Fig. $3 \mathrm{D}$ ) from the 3rd day of growth but the best rate of degradation was obtained on the $15^{\text {th }}$ day.

The fungal strains used in this work degraded PAHs and exhibited some ligninolytic activities following their growth in naphthalene, phenanthrene or anthracene.

$\mathrm{MnP}$ was the predominant ligninolytic activity detected in the supernatants of all the strains studied here. These results agree with those of Bogan and Lamar (3), where the fungus 


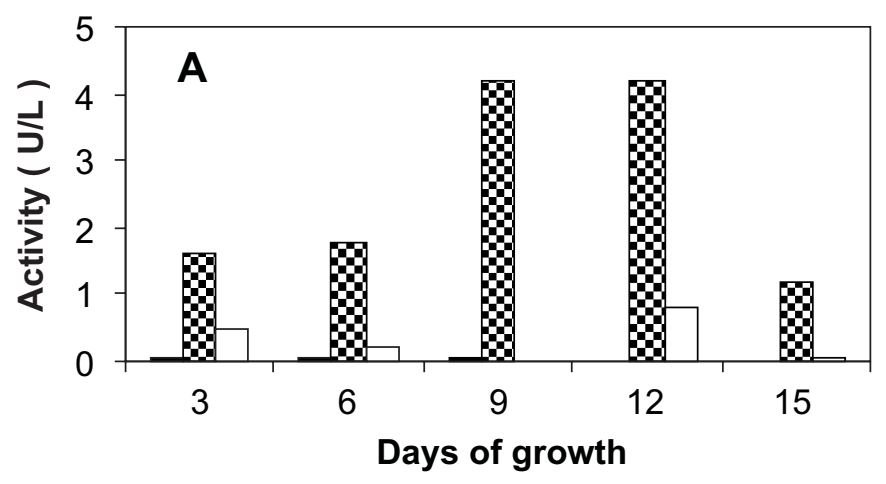

LiP $\$$ MnP $\square$ Laccase

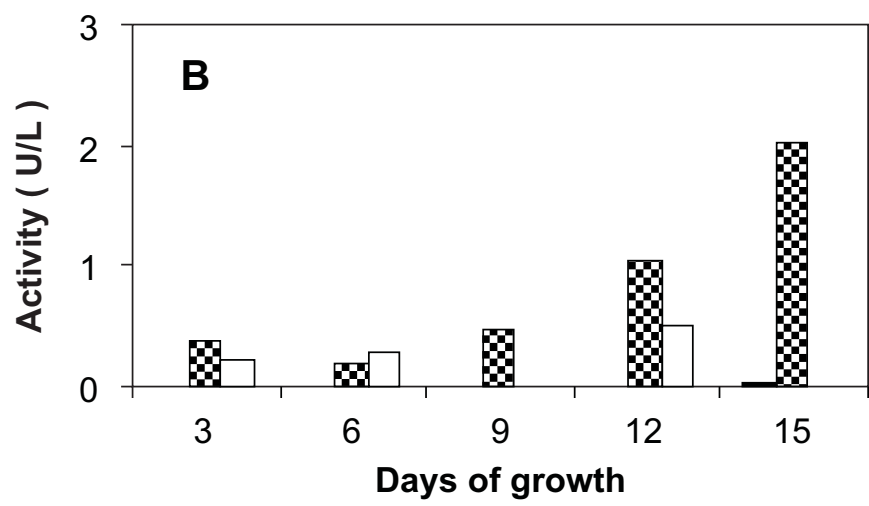

LiP $\$$ MnP $\square$ Laccase

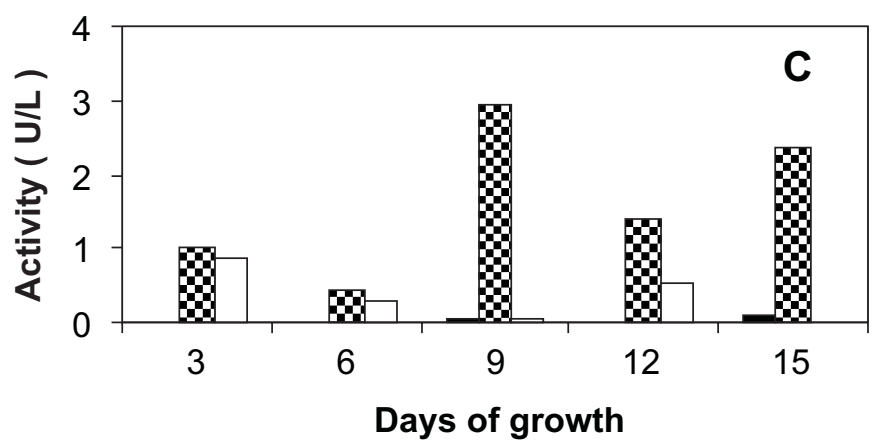

- LiP $\$ \mathrm{MnP} \quad \square$ Laccase

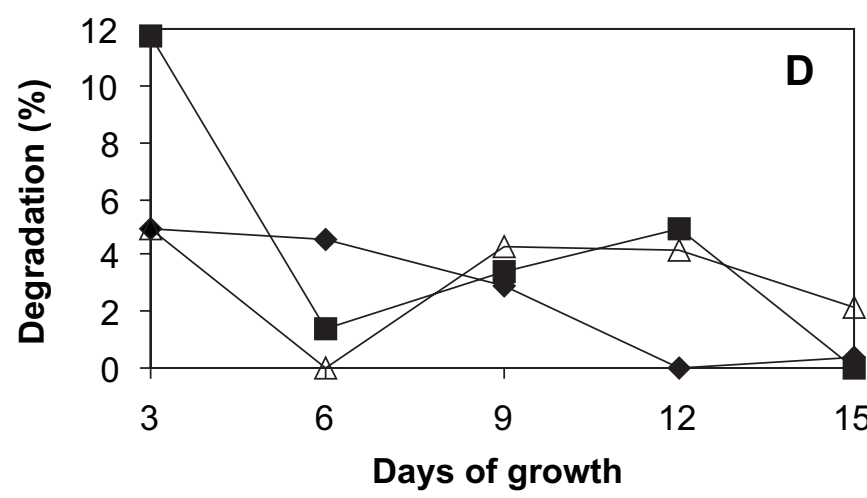

$\neg$ Strain $837 \multimap$ Strain $870 \multimap$ Strain 984

Figure 2. Activity of ligninolytic enzymes produced following growth of the strains in phenanthrene. A) enzyme activities of strain 837; B) enzyme activities of strain 870; C) enzyme activities of strain 984; D) degradation of 3 strains.

Phanerochaete laevis HHB-1625 degraded PAHs (anthracene, phenantrene, benzo(a) anthracene and benzo(a) pirene) in liquid medium, producing high MnP activity. This fungus similarly to the fungi used here also produced low levels of laccase, but no LiP, demonstrating the ability of $P$. laevis, a species whose ligninolytic system is dominated by $\mathrm{MnP}$, to cause extensive transformation of PAHs in vivo.

However, the white-rot fungi Phanerochaete chrysosporium, the most widely studied ligninolytic fungus, presented high levels of LiP and MnP, but no lacccase in liquid medium (11), conversely to our strains.

Launen et al. (20), reported that microorganisms degrade more efficiently PAHs with a lower number of aromatic rings in the molecule. Strains 984 degraded anthracene $(64 \% \pm 10 \%)$, which possesses 3 aromatic rings, as efficiently as naphthalene, which has 2 aromatic rings $(69 \% \pm 10 \%)$. However, strain 870 showed a greater efficiency degrading anthracene (53\%) than naphthalene $(17 \%)$.
Notable differences among these fungal strains with regard to the extent of ability to transform PAHs as well as the ligninolytic enzymes produced have been shown with these deuteromycete fungi. The ability of the various white-rot fungi species to transform PAHs and other pollutants is similarly quite variable. This variability is due to differences in both the enzymology of the various white-rot species and differences in growth and enzyme production responses of the fungi to different culture media (3). The degradation of PAHs by the deuteromycete fungal strains used here, provides an interesting means of investigating their ligninolytic enzyme system and also of comparing it with that of the white-rot fungi.

\section{ACKNOWLEDGEMENTS}

The authors wish to express their thanks to "Fundação de Amparo à Pesquisa do Estado de São Paulo" (FAPESP) for financing the experiment. 


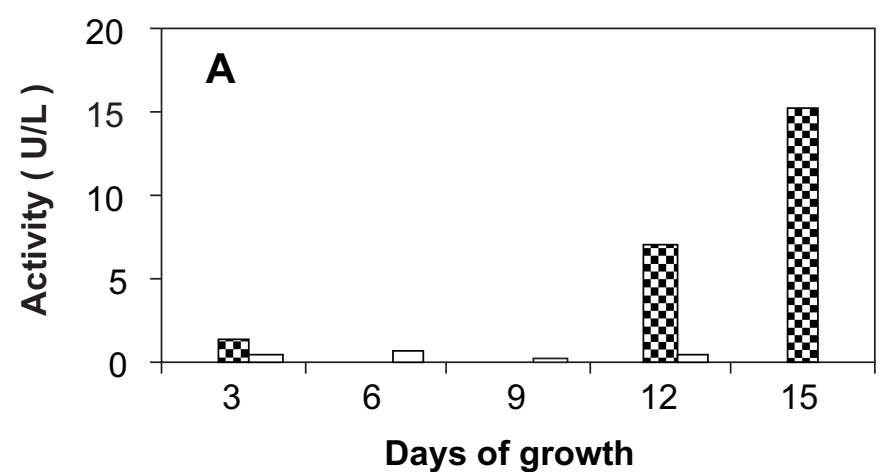

—iP $\mathrm{QMnP} \square$ Laccase

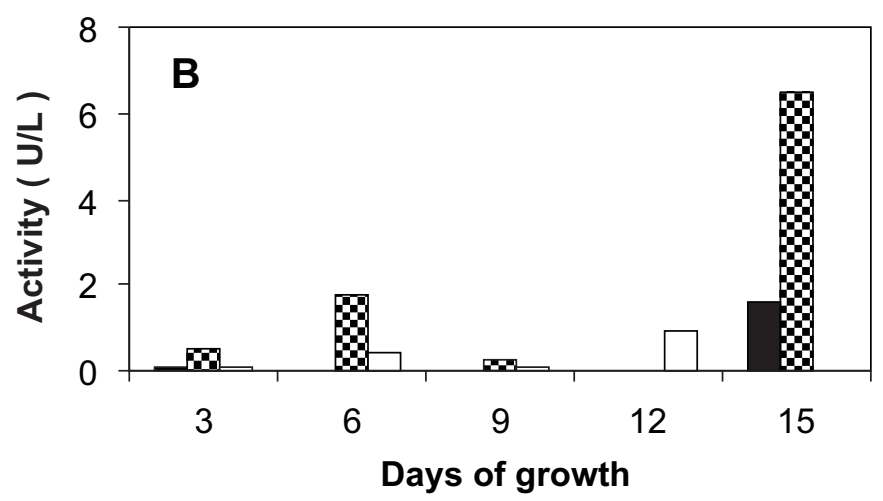

LiP $\mathrm{D}$ MnP $\square$ Laccase

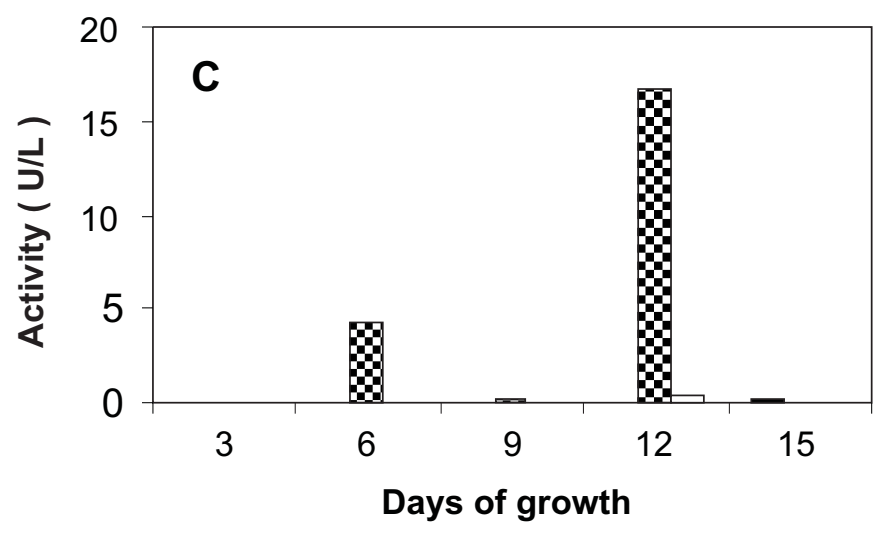

LiP $\$$ MnP $\square$ Laccase

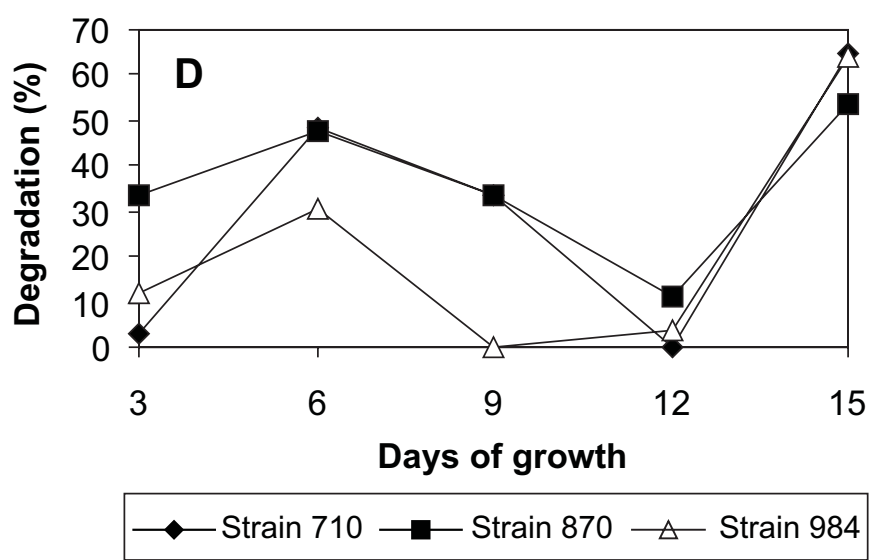

Figure 3. Activity of ligninolytic enzymes produced following growth of the strains in anthracene. A) enzyme activities of strain 710 ; B) enzyme activities of strain 870; C) enzyme activities of strain 984; D) degradation of 3 strains.

\section{RESUMO}

\section{Biodegradação de hidrocarbonetos aromáticos policíclicos por fungos do solo}

Treze fungos deuteromicetos ligninolíticos foram cultivados em meio contendo hidrocarbonetos aromáticos policíclicos (HAPs) por 6 e 10 dias. Os HAPs foram adicionados diretamente com o inóculo ou no terceiro dia de cultivo. A seleção das melhores linhagens foi baseada nos níveis de degradação dos HAPs e também nas atividades ligninolíticas produzidas pelas linhagens fúngicas. Essas melhores linhagens foram então cultivadas por 3, 6, 9, 12 e 15 dias. A degradação dos HAPs foi monitorada por cromatografia líquida de alta eficiência (CLAE) em uma coluna $\mathrm{C}_{18}$, variando para cada linhagem assim como as enzimas ligninolíticas presentes nos sobrenadantes das culturas. Alta degradação de naftaleno (69\%) foi obtida pela linhagem 984, tendo atividade de Mn-peroxidase, seguida pela linhagem
$870(17 \%)$ a qual apresentou atividades de lignina peroxidase e lacase. A melhor porcentagem de degradação de fenantreno (12\%) foi observada pela linhagem 870 contendo atividades de Mn-peroxidase e lacase. Quando antraceno foi utilizado como fonte de carbono, a linhagem 710 apresentou nível de degradação de $65 \%$.

Palavras-chave: biodegradação, enzimas ligninolíticas, hidrocarbonetos aromáticos policíclicos, fungos

\section{REFERENCES}

1. Barr, D.P.; Aust, S.D. Mechanisms white rot fungi use to degrade pollutants. Environ. Sci. Technol. 28: 79-87, 1994.

2. Benner, B.A.; Jr, Bryber, N.P.; Wise, S.A.; Mulholland, G.W.; Lao, R.C.; Fingas, M.F. Polycyclic aromatic hydrocarbons emissions from the combustion of crude oil on water. Environ. Sci. Technol. 24: 1418-1427, 1990.

3. Bogan, B.W.; Lamar, R. Polycyclic aromatic hydrocarbon-degrading of Phanerochaete chrysosoporium HHB - 1625 and its extracellular 
ligninolytic enzymes. Appl. Environ. Microbiol. 62(5): 1597-1603, 1996.

4. Boyle, D.; Wiesner, C.; Richardson, A. Factors affecting the degradtion of polyaromatic hydrocarbons in soil by white-rot fungi. Soil Biol. Biochem. 30(7): 873-882, 1998.

5. Carmichael, L.M.; Pfaender, F.K. The effect of inorganic and organic supplements on the microbial degradation of phenanthrene and pyrene in soils. Biodegradation 8: 1-13, 1997.

6. Cerniglia, C.E.; White, G.L.; Heflich, R.H. Fungal metabolism and detoxification of polycyclic aromatic hydrocarbons. Arch. Microbiol. 143: 105-110, 1985.

7. Cerniglia, C.E. Fungal metabolism of polycyclic aromatic hydrocarbons: past, present and future applications in bioremediation. J. Ind. Microbiol. Biotechnol. 19: 324-333, 1997.

8. Corsi, F.K.; Carvalho, D.F.; Durrant, L. R. Sistema ligninolítico e biosurfactantes produzidos por fungos utilizadores de hidrocarbonetos aromáticos policíclicos. Anais: II Reunião nacional de microbiologia aplicada ao meio ambiente. Florianópolis, 1998.

9. Dipple, A.; Cheng, S.C.; Bigger, C.A.H. Polycyclic aromatic hydrocarbons carcinogens. In: Pariza, M. W.; Aeschbacher, H. U.; Felton, J. S.; Sato, S. (Eds.), Mutagens in the diet. Wiley-Lissp., New York, pp. 109-127, 1990.

10. Fernandez, P.; Grifoll, A.M.; Solanas, A.M.; Bayona, J.M.; Albaiges, J. Biossay-directed chemical analysis of genotoxic components in coastal sediments. Environ. Sci. Technol. 26: 817829, 1992.

11. Field, J.A.; de Jong, E.; Costa, G.F.; de Bont, J.A.M. Screening for ligninolytc fungi applicable to the biodegradation of xenobiotcs. Trends Biotechnol. 11: 44-49, 1993.

12. Flowers, L.; Ohnishi, S.T.; Penning, T.M. DNA strand scission by polycuclic aromatic hydrocarbon $o$-quinones: role of reactive oxygen species, $\mathrm{Cu}(\mathrm{II}) / \mathrm{Cu}(\mathrm{I})$ redox cycling, and $o$-semiquinone anion radicals. Biochem. 36: 8640-8648, 1997

13. Freeman, D.J.; Catell, F.C.R. Woodburning as a source of atmospheric polycyclic aromatic hydrocarbons. Environ. Sci. Technol. 24: 1581$1585,1990$.
14. Higson, F.K. Degradation of xenobiotics by white rot fungi. Ver Environ.Contamin. Toxicol. 122: 111-152, 1991.

15. IARC. The evaluation of the carcinogenic risk of chemicals to humans. IARC. Monographis. Lyon, France, pp. 32-35, 1983-1985.

16. Jones, K.C.; Stratford, J.A.; Waterhouse, K.S.; Furlong, E.T. Giger, W.; Hites, R.A.; Schaffner, C.; Johnston, A.E. Increases in the polynuclear aromatic hydrocarbons content of as agricultural soil over the last century. Environ. Sci. Technol. 23: 95-101, 1989.

17. Kanga, S.A.; Bonner, J.S.; Page, C.A.; Mills, M.A.; Autenrieth, R.L. Solubilization of naphthalene and methyl-substituted naphthalenes from crude oil using biosurfactants. Environ. Sci. Technol. 31:556$561,1997$.

18. Kenneth, E.H. Mechanisms for polycyclic aromatic hidrocarbons degradation by ligninolytic fungi. Environ. Health Persrect. 103(5): 41-43, 1995.

19. Kuwahara, M.; Glenn, J.K.; Morgan, M.A.; Gold, M.H. Separation and charaterisation of two extracellular $\mathrm{H} 2 \mathrm{O} 2$ dependent oxidases from ligninolytic cultures of Phanerochaete chrysosporium. FEBS Lett. 169: 247-250, 1984.

20. Launen L.; Pinto, L.; Wiebe, C.; Kiehlmann, E.; Moore, M. The oxidation of pyrene and benzo[a]pyrene by nonbasidiomycete soil fungi. Can. J. Microbiol. 41: 477-488, 1995

21. Szklarz, G.D.; Antibus, R.K.; Sinsabaugh, R.L.; Linkins, A.E. Production of phenoloxidases and peroxidases by wood-rootting fungi. Mycol. 81: 234-240, 1989

22. Tien, M; Kirk, T.K. Lignin-degrading enzyme from Phanerochaete chrysosporium: purification, characterisation and catalytic properties of a unique $\mathrm{H}_{2} \mathrm{O}_{2}$ requiring oxygenase. Proc. Nat. Science USA 81: 2280-2284, 1984

23. Volkering, F.; Breure, A.M.; van Andel, J.G.; Rulkens, W.H. Influence of nonionic surfactants on biovailability and biodegradation of polycyclic aromatic hydrocarbons. Appl. Envirom. Microbiol. 61(5): 1699-1705, 1995.

24. Willumsen, P.A.; Karlson, U. Screening of bacteria, isolated from PAH-contaminated soils, production of biosurfactants and bioemulsifiers. Biodegradation 7: 415-423, 1997. 